\title{
Pengembangan Modul Berbasis Matematika Terapan pada Materi Matriks untuk Peserta Didik Kelas X SMK Jurusan Teknologi dan Rekayasa
}

\author{
Meila Asysyaffa $^{1}$, Joko Soebagyo ${ }^{2}$ \\ ${ }^{1,2}$ Pendidikan Matematika, Fakultas Keguruan dan Ilmu Pendidikan, Universitas Muhammadiyah Prof. Dr. Hamka, \\ Jl. Tanah Merdeka No.20, Rambutan, Pasar Rebo, Jakarta Timur, DKI Jakarta \\ masysyaffa@gmail.com
}

\begin{abstract}
This research is basically development research that produces teaching material products in the form of Applied Mathematics Modules for Matrix Materials in the Department of Modeling and Information in vocational mathematics learning with the subject matter of Matrix Concepts, Matrix Operations (Addition, Subtraction, Determinants, and Inverses) and their application. This study uses research and development (RND) with the ADDIE model through several stages, namely Analysis, Design, Development, Implementation, and Evaluation. Data collection techniques in this study were conducting teacher interviews and using questionnaires to materials and media experts to test the feasibility of the module, then questionnaires were given to 5 students of Class $\mathrm{X}$ Engineering Design Modeling and Building Information at SMKN 52 Jakarta as a small-scale trial, the last test was carried out large-scale trials to two class X Modeling and Building Information Design Techniques at SMKN 52 Jakarta to get products that are suitable for use in learning. based on the results of the study, the applied mathematics-based module on the Matrix material obtained an assessment of good criteria with a percentage of $86.5 \%$ from material experts and $79.5 \%$ from media experts. The results of the small-scale trial have good criteria with a percentage of $79.25 \%$ and $77.19 \%$ with very good criteria in large-scale trials. So, it can be said that the applied mathematics-based module on Matrix material is feasible and effective for students of SMKN 52 Jakarta. Keywords: Applied Mathematics, Matrix, ADDIE, Mathematics, Module
\end{abstract}

\begin{abstract}
Abstrak
Penelitian ini pada dasarnya merupakan penelitian pengembangan yang menghasilkan produk bahan ajar berupa Modul Matematika Terapan Materi Matriks Pada Jurusan Desain Pemodelan Dan Informasi Bangunan pada pembelajaran matematika SMK dengan pokok bahasan Konsep Matriks, Operasi Matriks (Penjumlahan, Pengurangan, Determinan, dan Invers) serta penerapannya. Penelitian ini menggunakan penelitian dan pengembangan (RND) dengan model ADDIE melalui beberapa tahap yaitu Analisis, Perancangan, Pengembangan, Implementasi, dan Evaluasi. Teknik pengumpulan data pada penelitian ini yaitu melakukan wawancara kepada guru dan menggunakan angket kepada ahli materi dan ahli media untuk menguji kelayakan modul, kemudian angket diberikan kepada 5 peserta didik Kelas X Teknik Desain Pemodelan dan Infromasi Bangunan SMKN 52 Jakarta sebagai uji coba skala kecil, terakhir dilakukan uji coba skala besar kepada dua kelas X Teknik Desain Pemodelan dan Infromasi Bangunan SMKN 52 Jakarta untuk mendapatkan produk yang layak untuk digunakan dalam pembelajaran. berdasarkan hasil penelitian, modul berbasis matematika terapan pada materi Matriks memperoleh penilaian berkriteria baik dengan presentase $86,5 \%$ dari ahli materi dan $79,5 \%$ dari ahli media. Hasil uji coba skala kecil memperoleh penilaian berkriteria baik dengan presentase 79,25\% dan 77,19\% dengan berkriteria sangat baik pada saat uji coba skala besar. Sehingga dapat disimpulkan bahwa modul berbasis matematika terapan pada materi Matriks layak dan efektif di gunakan untuk peserta didik SMKN 52 Jakarta.
\end{abstract}

Kata Kunci: Matematika Terapan, Matriks, ADDIE, Matematika, Modul

Copyright (c) 2021 Meila Asysyaffa, Joko Soebagyo

$\triangle$ Corresponding author: Meila Asysyaffa

Email Address: masysyaffa@gmail.com (Jl. Tanah Merdeka No.20, Jakarta Timur, Indonesia)

Received 25 July 2021, Accepted 29 August 2021, Published 12 October 2021

\section{PENDAHULUAN}

Pada masa globalisasi seperti saat ini, hampir seluruh kehidupan mengalami perkembangan baik dari segi teknologi, fashion tak luput dari sentuhan inovasi. Semua perkembangan yang terjadi tentu saja merupakan hasil jerih payah orang - orang hebat yang visioner, individu - individu yang memiliki kepedulian terhadap lingkungan sekitar sehingga bersedia mengobarkan tenaga, pikiran dan waktu 
untuk melakukan sebuah tindakan dalam rangka menciptakan ataupun memperbaiki segala sesuatu yang dirasa kurang agar mecapai fungsi optimal. Menurut KBBI Pengembangan merupakan "Sebuah proses cara, perbuatan mengembangkan". Artinya seseorang atau kelompok yang melakukan pengembangan, mereka adalah orang - orang tanggap dan memiliki kemajuan berfikir untuk membuat segala sesuatu menjadi lebih baik, lebih maju dan berguna bagi masyarakat luas (Dwi Ayuni, 2019).

Matematika merupakan salah satu mata pelajaran yang menduduki peran penting dalam dunia pendidikan. Kenyataannya dalam dunia pendidikan matematika dianggap susah, dan menakutkan, sehingga perlu adanya langkah baru yang mampu membuat peserta didik mudah dalam memahami matematika. Untuk dapat menjadikan matematika pelajaran yang mudah seseorang guru harus lebih kreatif dalam menyampaikan hal yang menggunakan media lain yang tidak hanya mengandalkan buku cetak saja (R. Y. A. S. A. Andriani, 2020). Menurut Hamalik dalam (Azhar, 2011) penggunaan media pembelajaran akan membantu keefektifan pembelajaran dalam menyampaikan isi materi pada saat itu. Salah satu bahan ajar yang dapa dikembangkan dalam proses pembelajaran adalah modul.

Modul pembelajaran merypaka bahan ajar yang dirancang secara sistematis didasari denga kurikulum yang berlaku dan dikemas kedalam bentuk satuan pembelajaran serta dapat dipelajari secara mandiri oleh pembaca dalam satuan waktu tertentu (Purwanto et al., 2007). Pembelajaran matematika di sekolah menengah kejuruan (SMK) khususnya bidang keahlian teknologi dan rekayasa berdasarkan Permendiknas No.16 tahun 2007 dan Perdirjen 464/D.D5/KR/2018 masih bersifat umum dan teoritis. Di sisi lain, revolusi industri 4.0 mensyaratkan hubungan antara mesin-mesin, manusia-mesin atau manusia-manusia. Pembelajaran matematika SMK bidang teknologi dan rekayasa, idealnya, pembelajaran matematika harusnya mamadukan kapilitas jurusan dan menunjang pengentahuan tentang matematika terapan, meliputi aspek keluasan, kedalam, relevansi dan keberlanjutan (Hine, 2015). Sebagai contoh pembelajaran matematika SMK pada jurusan Desain pembanguan dan informasi bangunan, baiknya menghubungkan matematika dengan ilmu desain pembangunan dan informasi bangungan, agar proses pembelajaran lebih kontekstual.

Untuk menciptakan pembelajaran kontekstual dibutuhkan konten bahan ajar matematika yang berkesinambungan dengan jurusan SMK khususnya pada SMK bidang keahlian teknologi dan rekayasa. (Sadri Hassani, 2009) mengatakan bahwa pedagogik terbaik untuk mengajarkan matematika kepada peserta didik teknik adalah dengan memperkenalkan dan menggunakan konsep-konsep dalam banyak aplikasi matematika yang diterapkan. Ketersedian bahan ajar materi matematika berbasis matematika terapan di SMK khususnya jurusan teknologi dan rekayasa belum cukup tersedia dengan baik. Hasil observasi awal terhadap buku sekolah elektronik (BSE) mata pelajaran matematika di SMK belum menunjukkan cakupan materi matematika terapan di dalamnya. Bahan ajar yag tersedia lebih banyak melibatkan prosedur yang memerluka basis pengetahuan untuk diterapkan di dunia praktis (Ojose, 2011). Sehingga ketersediaan bahan ajar ini menjadi kebutuhan yang harus segera dipenuhi.

Berdasarkan uraian yang telah dikemukakan penulis ingin melakukan penelitian tentang bahan ajar berupa modul yang sesuai dengan karakteristik peserta didik. sehingga tujuan pembelajaran 
matematika bisa tercapai. Pertama, penelitian yang dilakukan oleh (Gazali, 2016) dengan judul "Pengembangan Bahan Ajar Matematika untuk Siswa SMP Berdasarkan Teori Belajar Ausubel”. Hasil penelitian menunjukkan lebih dari 70\% siswa mencapai Kriteria Ketuntasan Minimum untuk pengetahuan dan keterampilan, serta mencapai kriteria baik dan sangat baik untuk ranah sikap. Kedua, penelitian dilakukan oleh (P. Andriani, 2020) dengan judul “ Pengembangan Video Pembelajaran Matematika Pada Materi Matriks Dengan Berbantuan Powtoon Untuk Meningkatkan Kemandirian Belajar Siswa”. Hasil penelitian kelayakan dari validasi ahli materi sebesar 93,18\%, oleh ahli media sebsar 91\%, respon siswa kwlas kecil sebesar 89\% dan respon siswa kelas besar sebesar 87,88\%. Penelitian yang dilakukan oleh (AGUSTINA, n.d.), menunjukan ada beberapa kesulitan yang dialami peserta didik SMK saat menyelesaikan soal matematika materi matriks yaitu peserta didik tidak bisa menentukan rumus dalam menyelesaiakan masalah, peserta didik tidak bisa melakukan operasi perhitungan dengan beneardan peserta didik tidak bisa menyelesaikan soal dalam bentuk cerita sampai akhir. Berdasarkan masalah yang telah dikemukakan peneliti merasa perlu melakukan penelitian dengan judul " Pengembangan Bahan Ajar Pembelajaran Matematika Terapan Pada Materi Matriks Untuk Peserta Didik Smk Jurusan Teknologi Dan Rekayasa".

\section{METODE}

\section{Tujuan, Lokasi dan Subjek Penelitian}

Tujuan dari penelitian ini adalah mengembangkan bahan ajar matematika berbasis matematika terapan materi matriks pada peserta didik kelas X di Sekolah Menengah Kejuruan (SMK) dan dilaksanakan di SMKN 52 Jakarta. Sebjek penelitian yaitu peserta didik kelas X Jurusan Desain Pemodelan dan Infromasi Bangunan. Jumlah subjek penelitian ini sebanyak 68 peserta didik.

\section{Metode dan Langkah - Langkah Penelitian}

Metode yang digunakan dalam penelitian ini adalah metode penelitian dan pengembangan (Research \& Development). Model pengembangan ADDIE yang dikemukaan oleh (Tegeh, I., Jampel, I., \& Pudjawan, 2014) yang terdiri dari 5 tahap yaitu hapa analisis (analyze), tahap rancangan (design), tahap pengembangan (development), tahap implementasi (implementation), dan tahap evaluasi (evaluation). Maka dari itu peneliti memilih model ADDIE karena langkah - langkah yang disusun secara bertahap dan sistematis. Rancangan model penelitin disajikan dalam bentuk bagan 1 .

Adapun penjelasan dari Bagan 1, Langkah pertama Analisis (Analyze) yang peneliti lakukan adalah menganalisis sembilan buku elektronik matematika terapan lalu menganalisis buku sekolah elektronik (BSE) matematika SMK guna mengetahui gambaran materinya yang masih dituliskan secara umum, analisis guru dilakukan dengan wawancara kepada guru bidang studi matematika mengenai bahan ajar apa saja yang digunakan saat melaksanakan pembelajaran kemudian untuk mengetahui perlu adanya pengembangan bahan ajar matematika yang berhubungan dengan bidang keahlian Desain Pemodelan dan informasi Bangunan. Serta analisis peserta didik guna menentukan bahan ajar seperti apa yang sedang dbutuhkan oleh peserta didik. Langkah kedua Desain (Design), Sebelum proses 
penyusunan dimulai, peneliti menentukan Kompetensi Inti (KI), Kompetensi Dasar (KD), tujuan pembelajar, konsep materi serta berbasis matematika terapan yang relavan dengan materi matriks dengan bantuan buku matematika terapan teknologi dan rekayasa(P. Andriani, 2020). Lalu merancang modul matematika perlu memperhatikan struktur, format, penulisan dalam modul, tampilan cover modul matematika yang menarik dan penyajian materi.

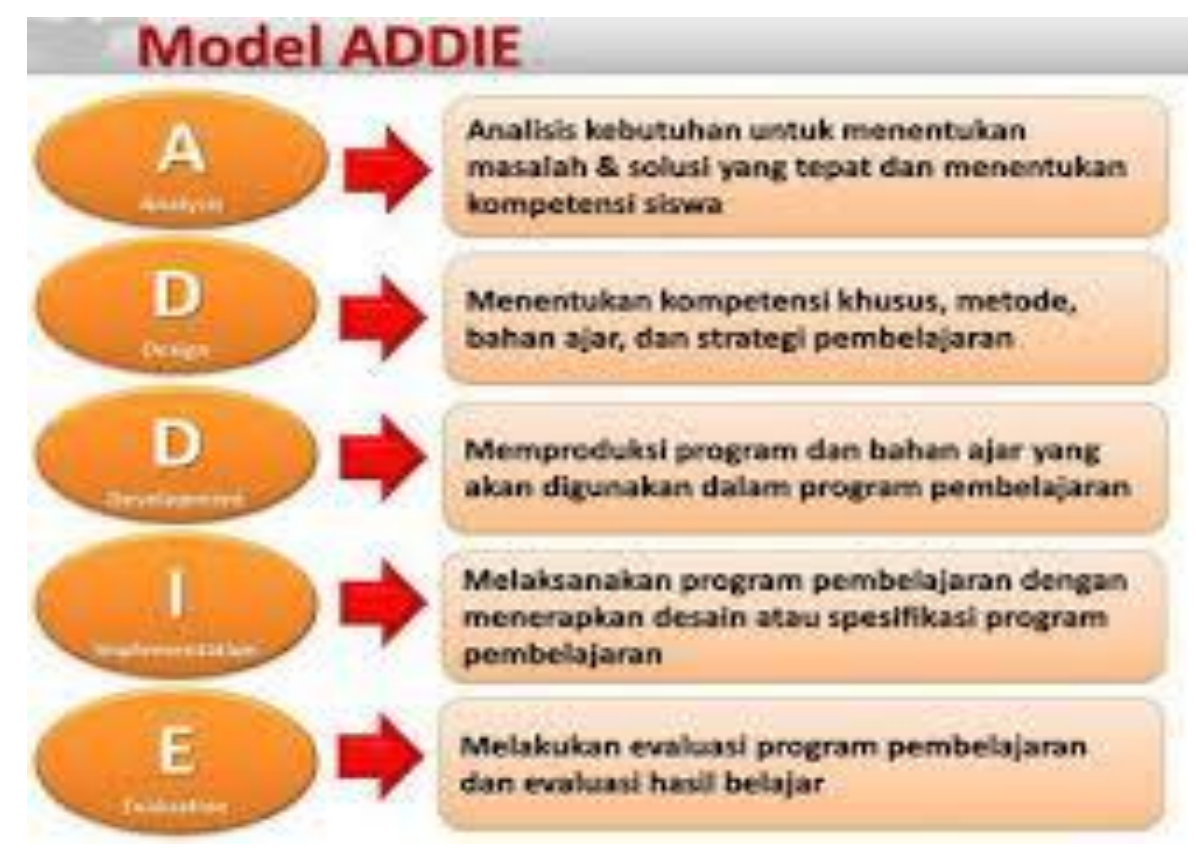

Bagan 1 Model ADDIE

Langkah ketiga Pengembangan (development), pada tahap ini peniliti mengembangkan modul matematika terapan materi matriks yang dibuat dengan bantuan 2 buku matematika BSE kelas X dan 1 buku matematika terapan. Selanjutnya modul akan melalui proses validasi oleh ahli materi dan ahli media untuk memberikan saran dan komentar atas perbaikan buku ajar. Langkah keempat Implementasi(implementation), setelah modul dinyatakan layak oleh ahli materi dan ahli media, modul akan di ujicobakan kepada peserta didik. Uji coba pertama dilakukan uji coba skala kecil terhadap 5 peserta didik, selanjutnya akan diuji cob skala besar terhadap 68 peserta didik. Langkah Kelima Evaluasi (Evalutation), ini merupakan tahap terakhir meliputi validasi yang dilakukan oleh ahli materi dan ahli media, hasil respon guru, hasil respon peserta didik pada uji coba skala kecil dan uji coba skala besar.

Jenis Data yang digunakan penulis dalam mengembangkan bahan ajar matematika terapan berupa data kuantitatif dan kualitatif. Data kuantitatif diperoleh melalui skor penilaian terhapa bahan ajar seperti penilaian oleh ahli materi dan ahli media, serta penilaian dari guru maupun peserta didik. Sedangkan kualitatif diperoleh melalui proses pengembangan bahan ajar seperti analisis buku matematika terapan, tanggapan serta saran dari para ahli materi.

Pada penelitian ini, instrumen validasi ahli, instrumen respon guru, serta instrumen respon siswa menggunakan skala Likert. Dalam penelitian dan pengembangan, skala Likert digunakan untuk 
mengembangkan instrumen yang digunakan untuk mengukur sikap, persepsi, dan pendapat seseorang terhadap suatu produk yang dikembangkan (Sugiyono, 2019a) dalam (P. Andriani, 2020).. Aturan pemberian skor pada instrumen tersebut yaitu:

Tabel 1 Aturan Penskoran Skala Likert

\begin{tabular}{|l|l|c|}
\hline No & \multicolumn{1}{|c|}{ Kategori } & Skor \\
\hline 1 & Sangat Baik & 5 \\
\hline 2 & Baik & 4 \\
\hline 3 & Kurang Baik & 3 \\
\hline 4 & Tidak Baik & 2 \\
\hline 5 & Sangat tidak Baik & 1 \\
\hline
\end{tabular}

Data kelayakan modul matematika terapan materi matriks ini berupa data deskritif presentase. Data yang diperoleh dari ahli materi, ahli media, guru serta peserta didik kemudian dihitung yaitu dengan menggunakan rumus berikut:

$$
\mathrm{P}=\frac{\Sigma \mathrm{X}}{\Sigma \mathrm{X}_{\mathrm{i}}} \times 100 \%
$$

Keterangan :

$\mathrm{P}=$ presentase kelayakan

$\Sigma \mathrm{X}=$ jumlah skor yang diperoleh

$\Sigma \mathrm{X}_{\mathrm{i}}=$ jumlah skor ideal (banyaknya individu)

Untuk menginterprestasikan presentase hasil penelitian, maka digunakan kriteria penilaian yang merupakan hasil konversi data kuantitatif menjadi kualitatif menggunakan teori sukardjo (Arif Z, M. A., \& Abdillah, 2018).

Tabel 2 Konversi Data Menjadi Kualitatif (Teori Sukardjo)

\begin{tabular}{|c|c|c|c|}
\hline Nilai & Rentang Skor & Persentase & Kriteria Penelitian \\
\hline A & $\tilde{X}>4,2$ & $81 \%-100 \%$ & Sangat Baik \\
\hline B & $3,4<\tilde{X} \leq 4,2$ & $61 \%-80 \%$ & Baik \\
\hline C & $2,6<\tilde{X} \leq 3,4$ & $41 \%-60 \%$ & Kurang Baik \\
\hline D & $1,8<\tilde{X} \leq 2,6$ & $21 \%-40 \%$ & Tidak Baik \\
\hline E & $\tilde{X} \leq 1,8$ & $0 \%-20 \%$ & Sangat Tidak Baik \\
\hline
\end{tabular}

\section{HASIL DAN DISKUSI}

Hasil dari penelitian dan pengembangan ini merupakan Modul Matematika Terapan pada materi matriks. Model pengembangan yang digunakan dalam penelitian ini adalah model pengembangan ADDIE, yang terdiri dari lima tahap yaitu tahap analisis (analysis), tahap rancangan (design), tahap pengembangan (development), tahap implementasi (implementation) dan tahap evaluasi (evaluation).

\section{Hasil Analisis Kebutuhan Guru dan Peserta Didik}

\section{Analisis Guru}

Berdasarkan wawancara yang dilakukan oleh peneliti dengan guru menunjukkan bahwa penggunaan modul pembelajaran dapat mempermudah guru dalam melakukan pembelajaran. Selain itu, 
modul pembelajaran memperjelas guru dalam memaparkan materi dan membantu siswa untuk memahami materi serta sumber untuk belajar mandiri. Modul pembelajaran juga membuat siswa menjadi termotivasi dalam belajar dengan bantuan penjelasan yang menarik.

\section{Analisa Peserta Didik}

Berdasarkan angket yang dibagikan kepada peserta didiik kelas X yang sedang mempelajari matriks menunjukan bahwa 54 dari 68 peserta didik sudah memiliki buku matematika untuk mempelajari matriks. Namun sebanyak 54 peserta didik atau sebesar 79,4\% peserta didik masih belum memahami materi matriks pada pembelajaran disekoalah tersebut. Berikut ini hasil diagram respon angek peserta didik, sebagai berikut:

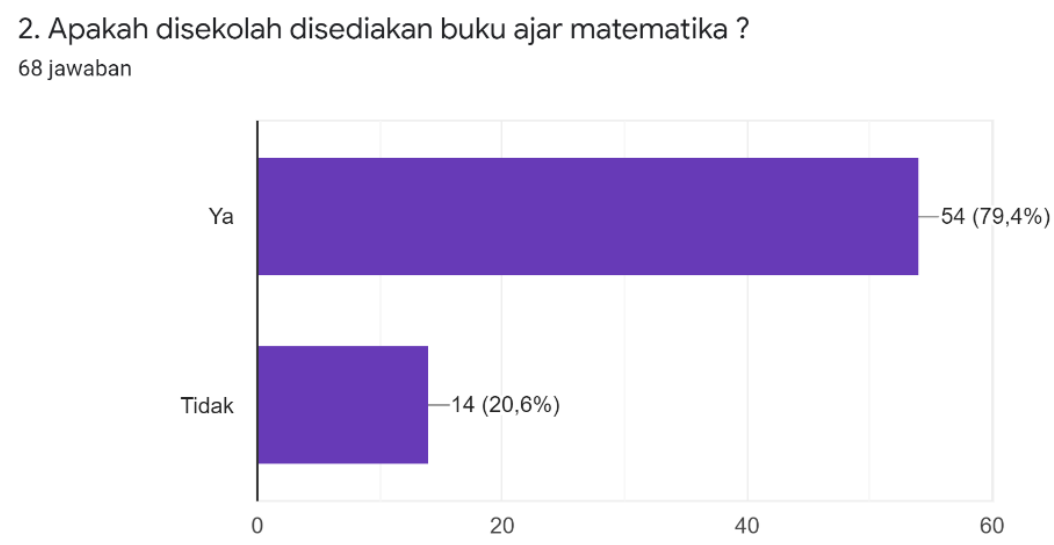

Gambar 1 Diagram Respon Angket Item Nomer 2

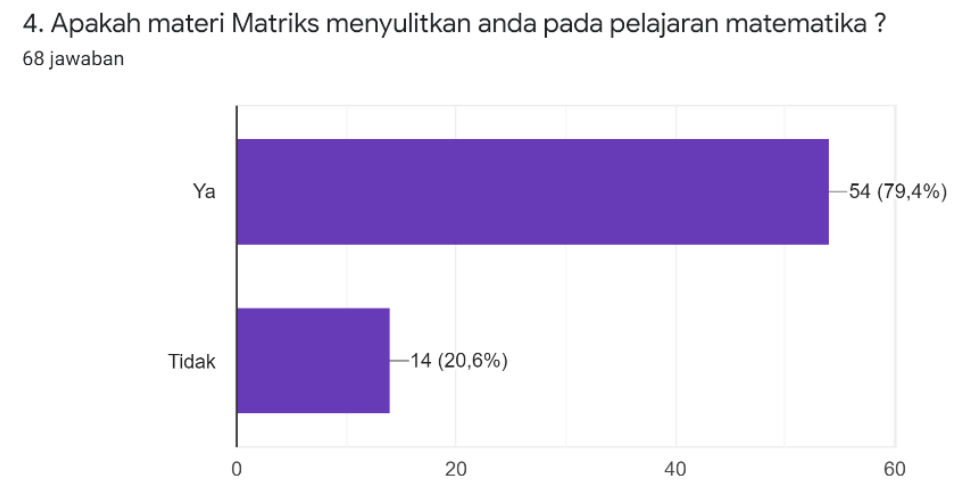

Gambar 2 Diagram Respon Angket Item Nomer 4

Hasil angket juga menunjukan bahwa 76,5\% peserta didik membutuhkan bahan ajar lain yang bisa digunakan untuk mempelajari matriks agar lebih mudah dipahami. Selain itu, 79,4\% peserta didik setuju apabila sebuah modul dibuat untuk menunjang dan membantu peserta didik dalam mempelajari materi matriks. Berikut ini hasil diagram respon angek peserta didik, sebagai berikut: 
9. Menurut anda, dalam mempelajari materi Matriks apakah dibutuhkan buku tambahan yang lebih menarik dan mudah dipahami ?

68 jawaban

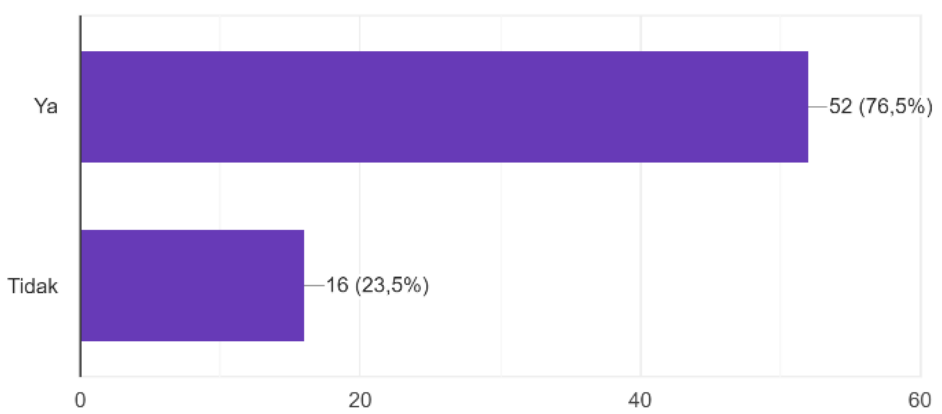

Gambar 3 Diagram Respon Angket Item Nomer 9

10. Apakah anda setuju dikembangkan sebuah buku pelajaran yang dihubungkan dengan materi di Jurusan Teknik Gambar Bangunan sebagai proses p... sehingga materi Matriks lebih mudah dipahami ? 68 jawaban

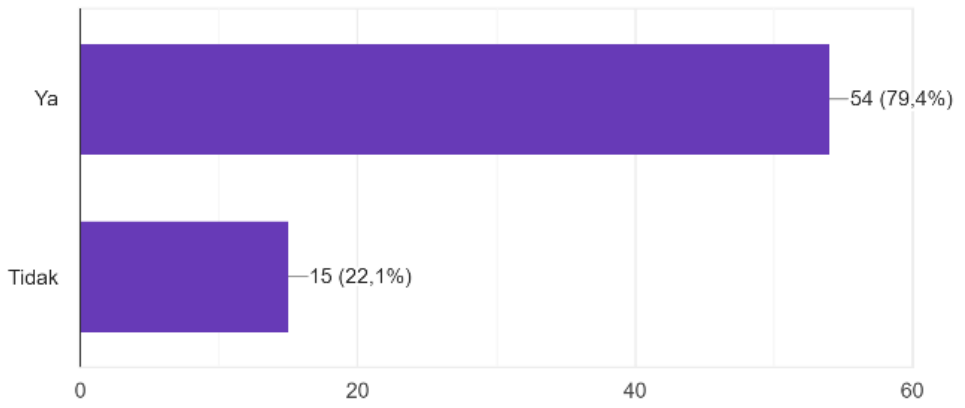

Gambar 4 Diagram Respon Angket Item Nomer 10

\section{Kelayakan Model}

Kelayakan modul pembelajaran matematika dapat diukur dari hasil validasi oleh para ahli materi dan para ahli media. Berikut ini rekapitulasi validasi modul pembelajaran matematika oleh ahli materi, diantaranya sebagai berikut:

Tabel 3 Hasil Rekapitulasi Validasi Ahli Materi

\begin{tabular}{|c|l|c|c|c|c|}
\hline \multirow{2}{*}{ No } & \multirow{2}{*}{$\begin{array}{c}\text { Indikator } \\
\text { Penilaian }\end{array}$} & $\mathbf{P 1}$ & $\mathbf{P 2}$ & $\bar{P}$ & \multirow{2}{*}{ Kategori } \\
\cline { 3 - 5 } & & & & \\
\hline 1 & Aspek Isi Materi & $80 \%$ & $97 \%$ & $88 \%$ & Sangat Baik \\
\hline 2 & Aspek Bahasa & $83 \%$ & $86 \%$ & $84,4 \%$ & Sangat Baik \\
\hline 3 & Aspek Kegunaan & $95 \%$ & $80 \%$ & $88 \%$ & Sangat Baik \\
\hline
\end{tabular}

Berdasarkan tabel 3 validasi modul matematika terapan oleh para ahli materi di atas dapat diketahui yang mendapatkan rata - rata persentase tertinggi diperoleh pada aspek isi materi dan Aspek kegunaan dengan persentase $88 \%$ berkriteria sangat baik. Selain itu aspek yang lainnya yaitu aspek bahasa dengan persentase $82,5 \%$. 
Selanjutnya untuk validasi oleh ahli media, berikut ini rekapitulasi validasi modul pembelajaran matematika oleh para ahli media, diantaranya sebagai berikut:

Tabel 4 Hasil Rekapitulasi Validasi Ahli Media

\begin{tabular}{|c|l|c|c|c|c|}
\hline \multirow{2}{*}{ No } & \multirow{2}{*}{ Indikator Penilaian } & \multicolumn{3}{|c|}{ Persentase } & \multirow{2}{*}{ Kategori } \\
\cline { 3 - 5 } & & P1 & P2 & $\bar{P}$ & \\
\hline 1 & Aspek Tampilan & $80 \%$ & $97 \%$ & $88 \%$ & Sangat Baik \\
\hline 2 & Aspek Keseimbangan Bahasa dan Gambar & $80 \%$ & $85 \%$ & $82,5 \%$ & Sangat Baik \\
\hline 3 & Aspek Keseuaian dengan Sasaran Pengguna & $84 \%$ & $80 \%$ & $82 \%$ & Sangat Baik \\
\hline
\end{tabular}

Berdasarkan tabel 4 validasi modul matematika terapan oleh para ahli media di atas dapat diketahui yang mendapatkan rata - rata persentase tertinngi diperoleh pada aspek tampilan dengan persentase $88 \%$ berkriteria sangat baik. Selain itu kedua aspek yang lainnya yaitu aspek keseimbangan bahasa dan gambar dengan persentase $82,5 \%$. Kemudian aspek kesesuaian dengan sasaran pengguna dengan persentase $82 \%$, kedua aspek tersebut pun berkriteria sangat baik. hasil validasi modul matematika terapan oleh ahli materi dan ahli media dapat direkap menjadi rata - rata persentase keseluruhan. Rata - rata persentase keseluruhan masing - masing ahli tersebut yaitu sebagai berikut:

Tabel 4 Rekapitulas Validasi oleh Para Ahli

\begin{tabular}{|c|l|c|c|c|c|}
\hline \multirow{2}{*}{ No } & \multirow{2}{*}{ Validasi Ahli } & \multicolumn{3}{|c|}{ Persentase } & \multirow{2}{*}{ Kategori } \\
\cline { 3 - 5 } & & P1 & P2 & $\bar{P}$ & \\
\hline 1 & Materi & $85 \%$ & $90 \%$ & $88 \%$ & Sangat Baik \\
\hline 2 & Media & $87,50 \%$ & $85 \%$ & $86,25 \%$ & Sangat Baik \\
\hline
\end{tabular}

Berdasarkan tabel 5 rekapitulasi hasil validasi oleh para ahli diantaranya dimana rata - rata persentase ahli materi diperoleh $80 \%$ dengan kriteria sangat baik dan rata - rata pesentase ahli media diperoleh $82 \%$ dengan kriteria baik. Hasil tersebut menunjukkan bahwa modul matematika terapan pada materi matriks untuk Kelas X SMK layak digunakan karena berkriteria sangat baik dan baik.

\section{Model Drat Modul Pembelajaran}

Berikut ini pengembangan modul berbasis matematika terapan pada materi matriks, draf tersebut sebgai berikut: 
Tabel 5. Model Draft Modul Pembelajaran

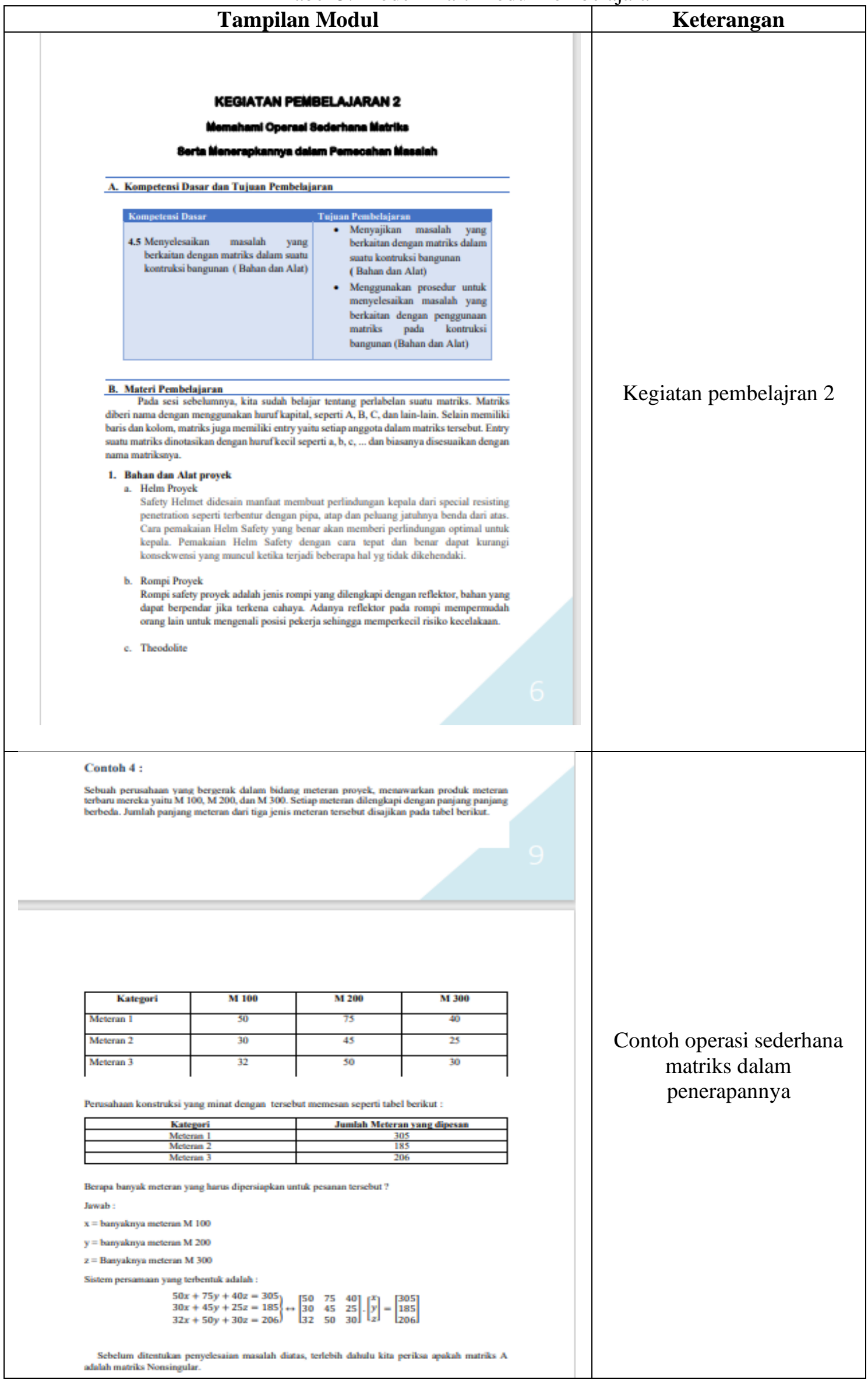




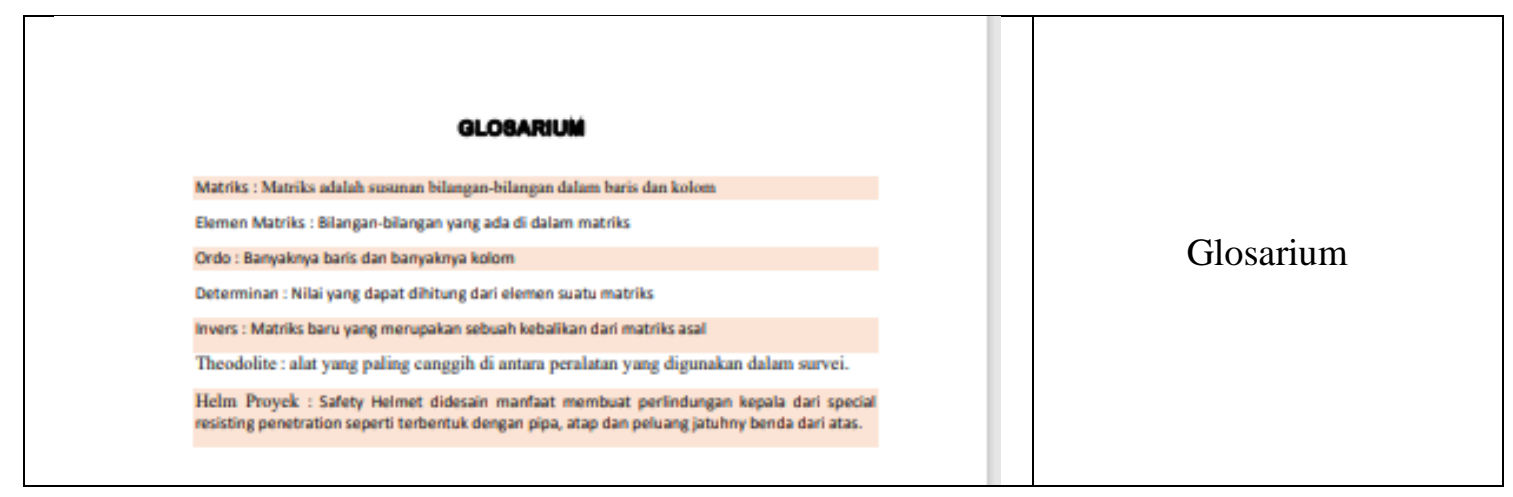

\section{Efektivitas Model}

Setelah dilakukan proses Validasi modul pembelajaran oleh para ahli, tahap selanjutnya yaitu menguji coba modul pembelajaran yang bertujuan untuk mengetahui tingkat kefektifan modul pembelajaran. Pengujian tersebut terbagi dua tahap, diantaranya yaitu sebagai berikut:

\section{Uji Coba Skala Kecil}

Pengujian modul pembelajaran pada uji coba skala kecil ini diajukan kepada dua orang guru bidang studi matematika serta 5 orang peserta didik kelas X SMKN 52 Jakarta. Berikut ini hasil Pengujian modul pembelajaran kepada dua orang guru bidang ahli matematika SMKN 52 Jakarta, yaitu sebagai berikut:

Tabel 6. Rekapitulasi Hasil Respon Guru

\begin{tabular}{|c|l|c|c|c|c|}
\hline \multirow{2}{*}{ No } & \multirow{2}{*}{ Indikator Penilaian } & \multicolumn{3}{|c|}{ Persentase } & \multirow{2}{*}{ Kategori } \\
\cline { 3 - 5 } & & P1 & P2 & $\bar{P}$ & \\
\hline 1 & Aspek Penyajian Materi & $80 \%$ & $97 \%$ & $88 \%$ & Sangat Baik \\
\hline 2 & Aspek Bahasa & $80 \%$ & $85 \%$ & $82,5 \%$ & Sangat Baik \\
\hline 3 & Aspek Tampilan & $84 \%$ & $80 \%$ & $82 \%$ & Sangat Baik \\
\hline 4 & Aspek Kegunaan & $95 \%$ & $90 \%$ & $93 \%$ & Sangat Baik \\
\hline
\end{tabular}

Berdasarkan Tabel 6 Hasil rekapitulasi respon guru matematika diketahui bahwa rata -rata persentase tertinggi diperoleh aspek kegunaan dengan persentase $90 \%$ berkriteria sangat baik. Kemudian ketiga aspek yang lain yaitu aspek penyajian materi dengan persentase $85 \%$, aspek bahasa dengan persentase $82,5 \%$ dan aspek tampilan dengan persentase $83 \%$, ketiga aspek tersebut berkriteria sangat baik. Selanjutnya pengujian modul matematika terapan yang dilakukan kepada peserta didik pada uji coba skala kecil dengan jumlah responden lima orang. Berikut hasil dari uji coba skala kecil terhadap peserta didik, sebagai berikut:

Tabel 7 Rekapitulasi Hasil Respon Peserta Didik Pada Uji Coba Skala Kecil

\begin{tabular}{|c|l|l|c|}
\hline No & Indikator Penilaian & Persentase & Kategori \\
\hline 1 & Aspek Ketertarikan & $80,60 \%$ & Baik \\
\hline 2 & Aspek Penyajian & $80,80 \%$ & Baik \\
\hline 3 & Aspek Bahasa & $75 \%$ & Baik \\
\hline \multicolumn{2}{|c|}{ Persentase Keseluruhan } & $79,25 \%$ & Baik \\
\hline
\end{tabular}


Berdasarkan Tabel 7 Hasil rekapitulasi respon peserta didik matematika diketahui bahwa rata rata persentase tertinggi diperoleh aspek penyajian dengan persentase $80,8 \%$ berkriteria baik. Kemudian ketiga aspek yang lain yaitu aspek ketertarikan dengan persentase $80,6 \%$ berkriteria baik dan aspek bahasa dengan persentase $75 \%$ berkriteria baik. maka dari itu persentase keseluruhan dari dari ketiga aspek tersebut $79,25 \%$ yang berkriteria baik.

\section{Uji Coba Skala Besar}

Setelah melakukan uji coba pada skala kecil, selanjutnya dilakukan pengujian modul pembelajaran pada uji coba skala besar dengan banyak responden 68 orang yang terbagi dalam dua rombongan belajar yaitu kelas X - A dan X - B SMKN 52 Jakarta. Berikut ini hasil pengujian modul pembelajaran terhadap peserta didik pada uji coba skala besar, yaitu sebagai berikut:

Tabel 8 Rekapitulasi Hasil Respon Peserta Didik Pada Uji Coba Skala Besar

\begin{tabular}{|c|l|l|c|}
\hline No & Indikator Penilaian & persentase & Kategori \\
\hline 1 & Aspek Ketertarikan & $77,80 \%$ & Baik \\
\hline 2 & Aspek Penyajian & $78,40 \%$ & Baik \\
\hline 3 & Aspek Bahasa & $75 \%$ & Baik \\
\hline \multicolumn{2}{|c|}{ Persentase Keseluruhan } & $77,19 \%$ & Baik \\
\hline
\end{tabular}

Berdasarkan Tabel 8 Hasil rekapitulasi respon peserta didik matematika diketahui bahwa ratarata persentase tertinggi diperoleh aspek penyajian dengan persentase $78,4 \%$ berkriteria baik. Kemudian ketiga aspek yang lain yaitu aspek ketertarikan dengan persentase $77,8 \%$ berkriteria baik dan aspek bahasa dengan persentase $74,7 \%$ berkriteria baik. Maka dari itu persentase keseluruhan dari dari ketiga aspek tersebut $77,19 \%$ yang berkriteria baik.

\section{HASIL DAN DISKUSI}

Validasi oleh para ahli materi mencakup indikator yaitu aspek isi materi, aspek bahasa dan aspek kegunaan. Hasil rekapitulasi validasi modul matematika terapan oleh para ahli materi dapat diketahui yang mendapatkan rata - rata persentase tertinggi diperoleh pada aspek isi materi dan Aspek kegunaan dengan persentase $88 \%$ berkriteria sangat baik. Selain itu aspek yang lainnya yaitu aspek bahasa dengan persentase $82,5 \%$. Berdasarkan rekapitulasi hasil validasi oleh para ahli diantaranya dimana rata-rata persentase ahli materi diperoleh $80 \%$ dengan kriteria sangat baik dan rata-rata pesentase ahli media diperoleh $82 \%$ dengan kriteria baik. Hasil tersebut menunjukkan bahwa modul matematika terapan pada materi matriks untuk Kelas X SMK layak digunakan karena berkriteria sangat baik dan baik.

Tahap Implementasi (implementation) yaitu setelah modul dinyatakan layak oleh ahli materi dan ahli media, modul akan di ujicobakan kepada guru dan peserta didik. Pengujian modul matematika terapan terdiri dari uji coba skala kecil dan uji coba skala besar. Modul matermatika terapan yang diujikan kepada guru mencakup aspek penyajian materi, aspek bahasa, aspek tampilan, dan aspek kegunaan Pada uji coba skala kecil, modul matematika terapan akan diujicobakan kepada dua orang 
guru matematika.Hasil rekapitulasi respon guru matematika diketahui bahwa rata -rata persentase tertinggi diperoleh aspek kegunaan dengan persentase $90 \%$ berkriteria sangat baik. Kemudian ketiga aspek yang lain yaitu aspek penyajian materi dengan persentase $85 \%$, aspek bahasa dengan persentase $82,5 \%$ dan aspek tampilan dengan persentase $83 \%$, ketiga aspek tersebut berkriteria sangat baik.

Selanjutnya, modul berbasis matermatika terapan yang akan diujikan kepada peserta didik mencakup aspek ketertarikan, aspek penyajian, dan aspek bahasa. Pada uji coba skala kecil, modul matematika terapan akan diujicobakan kepada 5 orang peserta didik matematika. Hasil rekapitulasi respon peserta didik matematika diketahui bahwa rata -rata persentase tertinggi diperoleh aspek penyajian dengan persentase $80,8 \%$ berkriteria baik. Kemudian ketiga aspek yang lain yaitu aspek ketertarikan dengan persentase $80,6 \%$ berkriteria baik dan aspek bahasa dengan persentase $75 \%$ berkriteria baik. maka dari itu persentase keseluruhan dari dari ketiga aspek tersebut $79,25 \%$ yang berkriteria baik.

Pada uji coba skala besar akan dilakukan terhadap 68 orang peserta didik di kelas X SMKN 52 Jakarta. Hasil rekapitulasi respon peserta didik matematika diketahui bahwa rata -rata persentase tertinggi diperoleh aspek penyajian dengan persentase 78,4\% berkriteria baik. Kemudian ketiga aspek yang lain yaitu aspek ketertarikan dengan persentase $77,8 \%$ berkriteria baik dan aspek bahasa dengan persentase $74,7 \%$ berkriteria baik. maka dari itu persentase keseluruhan dari dari ketiga aspek tersebut $77,19 \%$ yang berkriteria baik.

\section{KESIMPULAN}

Berdasarkan penelitian dan pengembangan bahan ajar matematika terapan pada materi matriks untuk peserta didik kelas X SMK jurusan teknologi dan rekayasa diantaranya yaitu: a) Pada penelitin ini telah dikembangkan bahan ajar pembelajaran matematika maetri matriks dengan menggunakan model ADDIE, dikembangkan dengan beberapa tahap diantaranya analisis (analysis) tahap ini peneliti mencari informasi kebutuhan pembelajaran kepada peserta didik; perancangan (design) peneliti menentukan bahan ajar dan merancang produk; pengembangan (development) peneliti melakukan validasi terhadap produk awal dan setelah itu di uji cobakan kepada subjek penelitian dengan uji coba skala kecil dan uji coba skala besar untuk mendapatkan revisi dan menghasilkan produk akhir; penerapan (implementation) pada tahap ini menghasilkan produk yang sudah diperbaiki dari validator. b) Validasi modul matematika terapan pada materi matriks mendapatkan penilaian kriteria baik oleh ahli materi dengan presentase $80 \%$ dan penilaian berkriteria sangat baik oleh ahli media dengan persentase $82 \%$. c) Kelayakan modul matematika terapan pada materi matriks kelas X SMK pada uji coba skala kecil memperoleh 79,25\% masuk dalam kriteria baik dan uji coba skala besar memperoleh $77,19 \%$ masuk dalam kriteria baik.

\section{REFERENSI}

Agustina, N. (n.d.). Analisis Kesulitan Siswa Dalam Menyelesaikan Soal Matematika Materi Matriks 
Kelas XI SMK Muhammadiyah 1 Palembang. http://repository.radenfatah.ac.id/5363/

Andriani, P. (2020). Pengembangan Video Pembelajaran Matematika Pada Materi Matriks Dengan Berbantuan Powtoon Untuk Meningkatkan Kemandirian Belajar Siswa. Jurnal Ilmiah Mandala Education, 6(2), 482.

Andriani, R. Y. A. S. A. (2020). Pengembangan Video Media Pembelajaran Matematika Dengan Bantuan Powtoon. Jurnal Pemikiran Dan Penelitian Pendidikan Matematika (JP3M), 2(2), 8596. https://doi.org/10.36765/jp3m.v2i2.29

Arif Z, M. A., \& Abdillah, A. (2018). engembangan Modul Belajar Mandiri LaTeX Beamer Sebagai Alternatif Media Presentasi Mahasiswa Program Studi Pendidikan Matematika. Jurnal Teori Dan Aplikasi Matematika, 2(2), 138-143. https://doi.org/10.31764/jtam.v2i2.716

Azhar. (2011). media pembelajaran. Bab II Kajian Teori, 1, 9-34.

Dwi Ayuni. (2019). Research and Development: Penelitian Yang Produktif Dalam Dunia Pendidikan. Research Gate, August. https://doi.org/10.13140/RG.2.2.28521.44640

Gazali, R. Y. (2016). Pengembangan bahan ajar matematika untuk siswa SMP berdasarkan teori belajar $\begin{array}{lllll}\text { ausubel. PYTHAGORAS: Jurnal Pendidikan Matematika, } 11(2), & 182 .\end{array}$ https://doi.org/10.21831/pg.v11i2.10644

Hine, G. S. C. (2015). Strengthening Pre-service Teachers' Mathematical Content Knowledge. Ournal of University Teaching and Learning Practice, 12(4), 1-11.

Ojose, B. (2011). Mathematics literacy : are we able to put the mathematics we learn into everyday use? Journal of Mathematics Education, 4(1), 89-100.

Purwanto, Rahadi, A., \& Lasmono, S. (2007). Pengembangan Modul (Purwanto (ed.)). https://issuu.com/download-bse/docs/buku_pengembangan_modul_full

Sadri Hassani. (2009). Mathematial Methods.

Tegeh, I., Jampel, I., \& Pudjawan, K. (2014). Model Penelitian Pengembangan (Pertama). Yogyakarta: Graha Ilmu. 